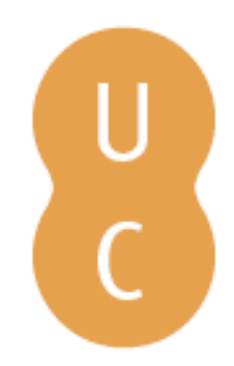

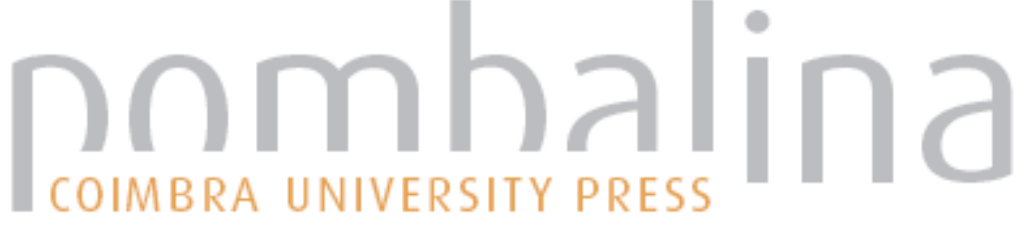

\section{A colecção de vasos gregos do museu de farmácia}

\author{
Autor(es): $\quad$ Morais, Rui
}

Publicado por: Imprensa da Universidade de Coimbra

URL

persistente: URI:http://hdl.handle.net/10316.2/2356

DOI: $\quad$ DOI:http://dx.doi.org/10.14195/978-989-26-0210-3

Accessed : $\quad$ 26-Apr-2023 13:20:39

A navegação consulta e descarregamento dos títulos inseridos nas Bibliotecas Digitais UC Digitalis, UC Pombalina e UC Impactum, pressupõem a aceitação plena e sem reservas dos Termos e Condições de Uso destas Bibliotecas Digitais, disponíveis em https://digitalis.uc.pt/pt-pt/termos.

Conforme exposto nos referidos Termos e Condições de Uso, o descarregamento de títulos de acesso restrito requer uma licença válida de autorização devendo o utilizador aceder ao(s) documento(s) a partir de um endereço de IP da instituição detentora da supramencionada licença.

Ao utilizador é apenas permitido o descarregamento para uso pessoal, pelo que o emprego do(s) título(s) descarregado(s) para outro fim, designadamente comercial, carece de autorização do respetivo autor ou editor da obra.

Na medida em que todas as obras da UC Digitalis se encontram protegidas pelo Código do Direito de Autor e Direitos Conexos e demais legislação aplicável, toda a cópia, parcial ou total, deste documento, nos casos em que é legalmente admitida, deverá conter ou fazer-se acompanhar por este aviso.

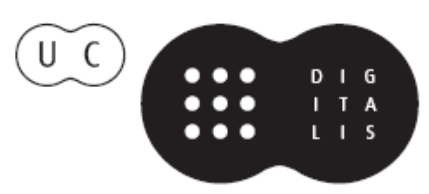




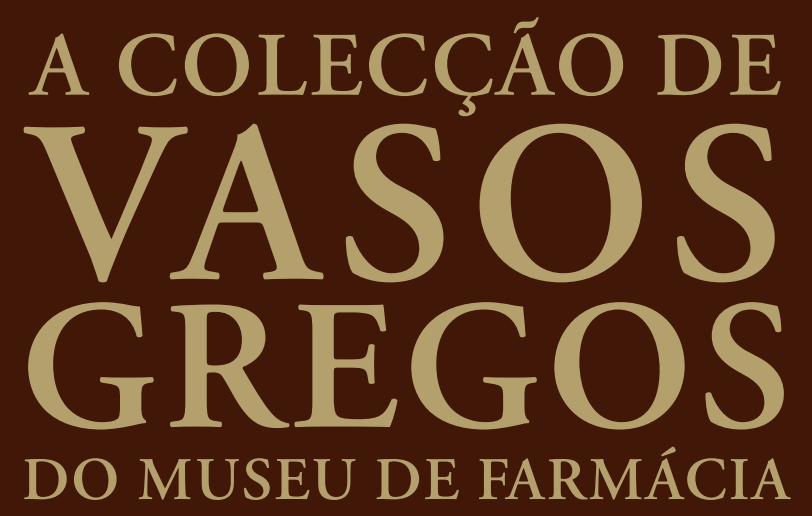

RUI MORAIS

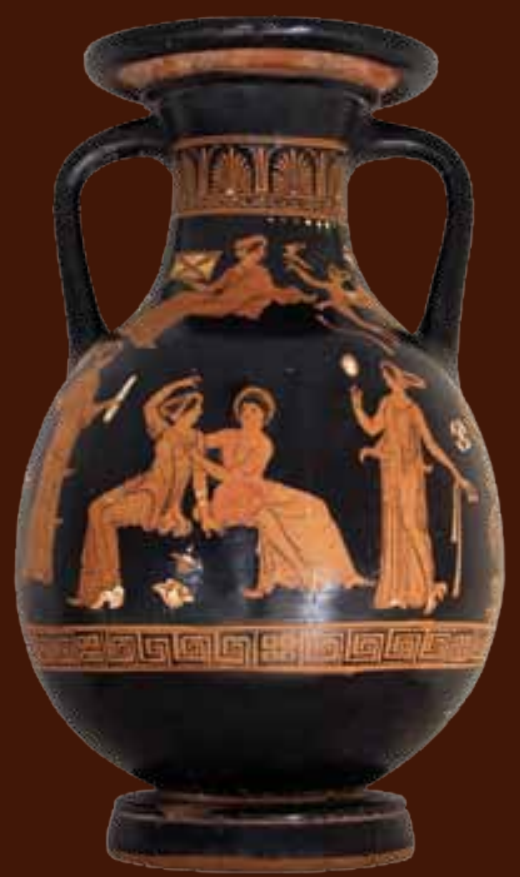


(Página deixada propositadamente em branco) 
CLASSICA

INSTRVMENTA 



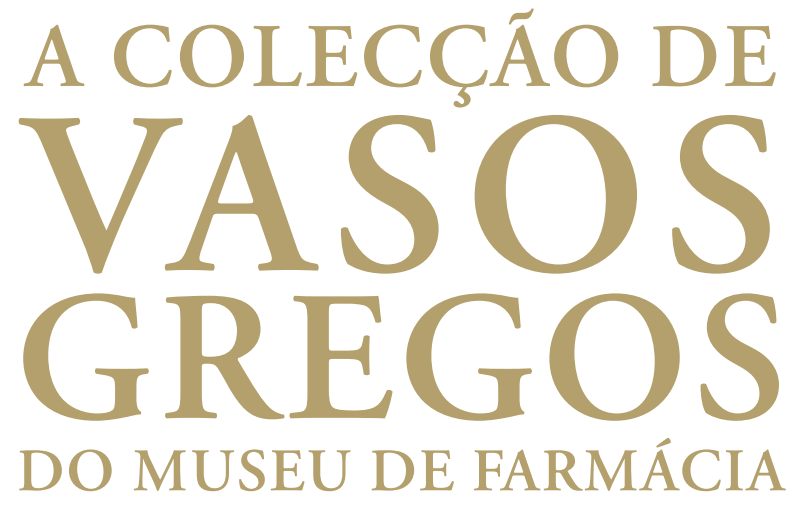


Título • A colecçáo de Vasos Gregos do Museu de Farmácia

Autor • Rui Morais

\section{FICHA TÉCNICA}

\section{ClASSiCA INSTRVMENTA - Monografias de História de Arte e Arqueologia}

\section{Coordenador Científico do Plano de ediçẫo: Maria do Céu Filho}

\section{Comissão Redactorial}

José Ribeiro Ferreira

Maria de Fátima Silva

\section{Director Técnico: Delfim Leão}

\section{Conselho Editorial}

Adolfo Fernández Fernández | Vigo

Amílcar Guerra | Lisboa

Ángel Morillo Cerdán | Madrid

Carlos Fabião | Lisboa

Luísa de Nazaré Ferreira | Coimbra

\section{EDIÇÃo}

Imprensa da Universidade de Coimbra

URL: http://www.uc.pt/imprensa_uc

E-mail: imprensa@uc.pt

Vendas online:

http://livrariadaimprensa.uc.pt

CoORdenAÇÁ̃o EDITORIAL

Imprensa da Universidade de Coimbra

ConceÇão gráficA

António Barros

INFOGRAFIA

Carlos Costa
Francisco de Oliveira

Nair Castro Soares
Maria Helena da Rocha Pereira | Coimbra Nuno Simôes Rodrigues | Lisboa

Pedro Carvalho | Coimbra

Rui Morais | Braga/Coimbra

\section{Créditos Fotográficos}

Pedro Medeiros

Impressáo e Acabamento

Sereer

ISBN

978-989-26-0134-2

\section{ISBN DIGITAL}

978-989-26-0210-3

DoI

http://dx.doi.org/10.14195/978-989-26-0210-3

Depósito LegAL

$338283 / 11$

\section{Obra Publicada com o apoio de:}

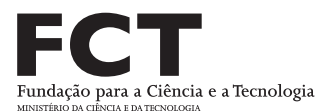

\section{$\mathrm{POCI} / 2010$}

\section{(c) Dezembro $201 \mathrm{I}$.}

IMPRENSA DA UNIVERSIDADE DE COIMBRA

Classica Digitalia Vniversitatis Conimbrigensis (http://classicadigitalia.uc.pt)

Centro de Estudos Clássicos e Humanísticos da Universidade de Coimbra

Reservados todos os direitos. Nos termos legais fica expressamente proibida a reproduçáo total ou parcial por qualquer meio, em papel ou em ediçấo electrónica, sem autorização expressa dos titulares dos direitos. É desde já excepcionada a utilização em circuitos académicos fechados para apoio a leccionação ou extensão cultural por via de e-learning. 


\section{SUMÁRIO}

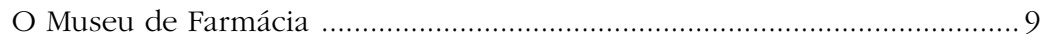

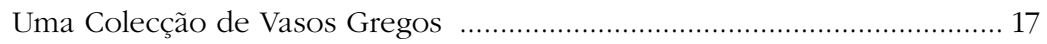

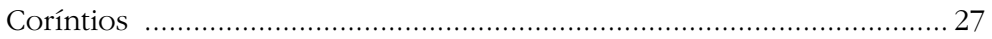

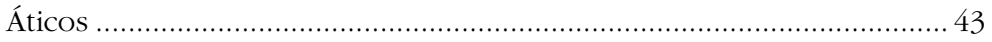

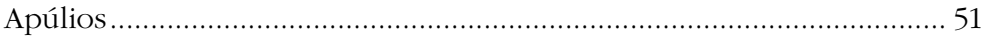

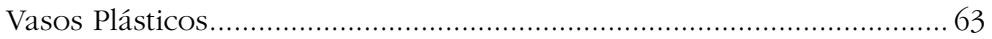

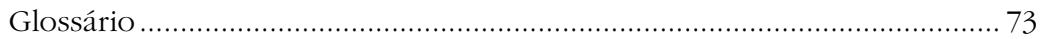

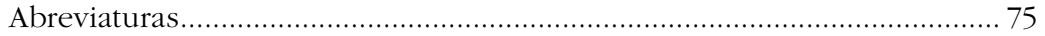

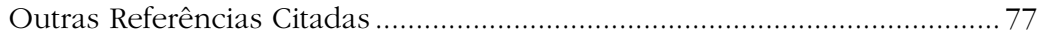


(Página deixada propositadamente em branco) 
A Maria Helena da Rocha Pereira, Mestre no estudo dos Vasos Gregos. 

O MUSEU DE FARMÁCIA 


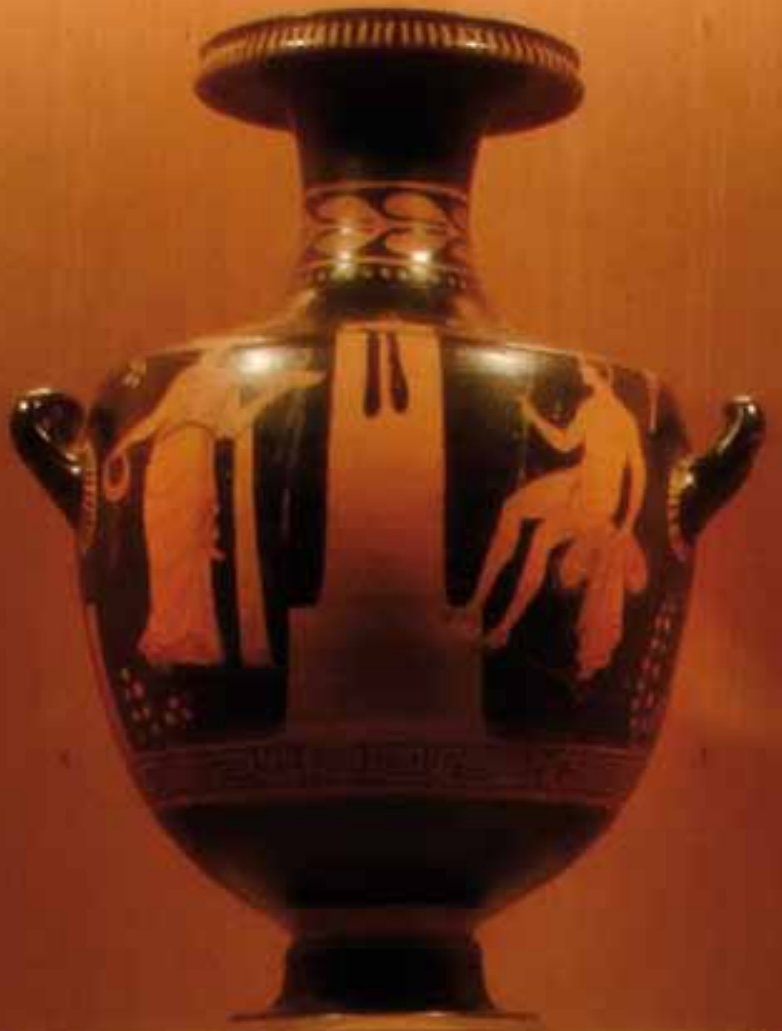


O Museu da Farmácia nasceu de um gesto individual em 1981, com a doação da sua colecção particular, pela parte do Dr. Salgueiro Basso, à Associação Nacional das Farmácias.

Com o objectivo de formar o Museu, sensibilizou os associados no sentido de contribuírem para o ainda quase inexistente espólio do Museu. De imediato se tornou um projecto comum a todos os farmacêuticos. A recolha de peças em farmácias de todo o País, a sua classificação e inventariação foi uma constante, até que em Junho de 1996, o Museu foi finalmente uma realidade. Inaugurado nessa ocasião, o Museu da Farmácia é o resultado de uma vontade inequívoca das Farmácias Portuguesas e da Direcção da Associação Nacional das Farmácias.

Enquadrado numa política concertada de recuperação do património, o Museu da Farmácia evitou que se perdesse um valioso património em risco de destruição e desaparecimento - que o Estado português muito dificilmente, teria possibilidade de preservar. Tendo-se multiplicado em esforços para a sua recolha, preservação e conservação, conseguiu reunir todo um espólio nacional representativo de uma profissão.

A sua colecção conta já com inúmeros objectos que preservam a memória da profissão farmacêutica e o seu património cultural e histórico, reflectindo a enorme importância que o farmacêutico tem na sociedade enquanto especialista do medicamento.

Para além deste esforço de recolha e de salvaguarda do património nacional, o Museu da Farmácia tem vindo a reunir uma colecção representativa da história da farmácia e da saúde ao longo do tempo, nos povos e nas culturas do mundo inteiro. É um museu inovador, que apresenta de uma forma global a diversidade de interpretações e curas da doença, que o homem encontrou ao longo de 5.000 anos, em diversas civilizações e culturas. 


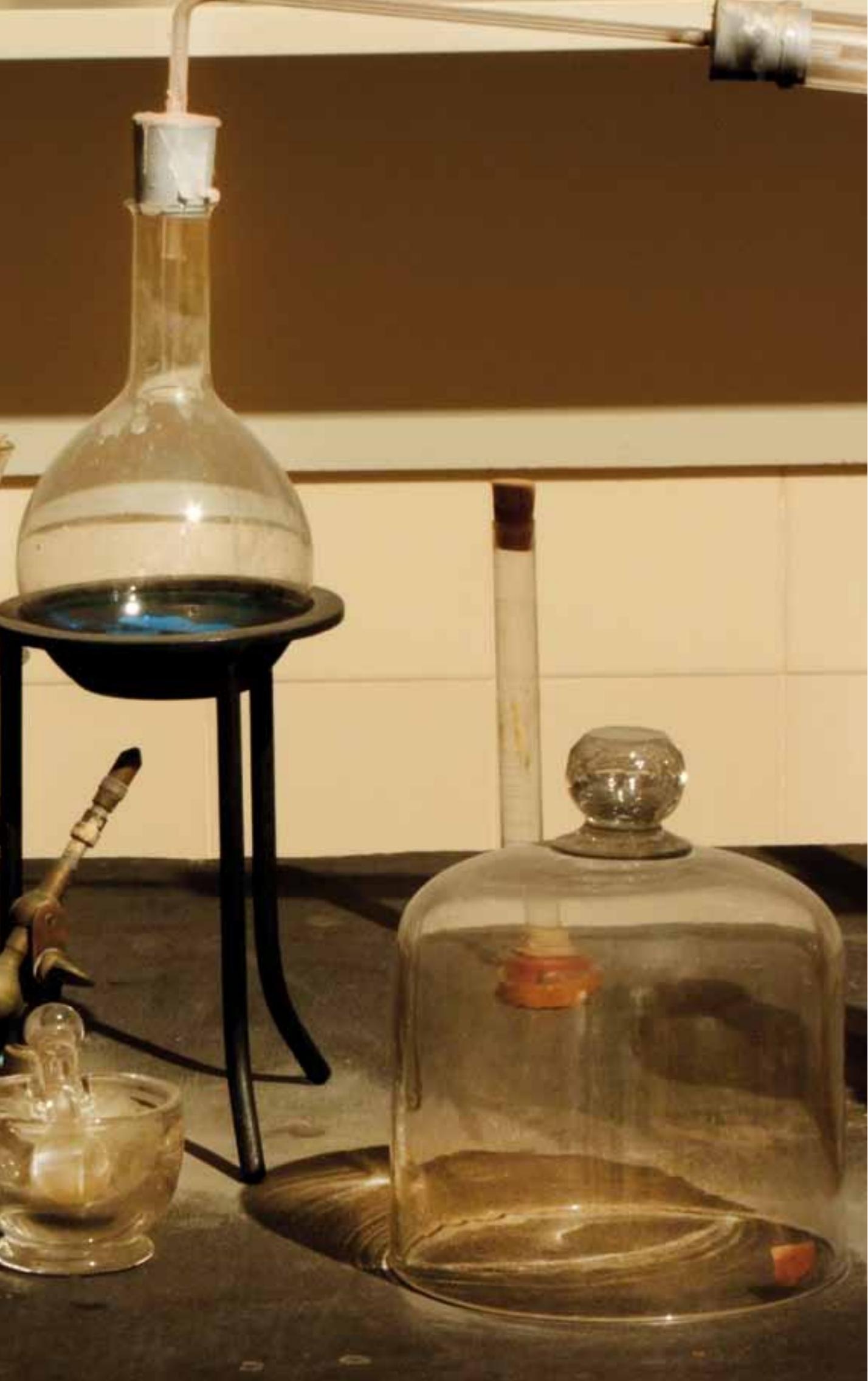


A abrangência do Museu permite-lhe alcançar todo o tipo de público ao qual apresenta um cuidadoso serviço educativo, com especial incidência na área da educação para a saúde. Destaca-se ainda a organização de seminários, conferências e palestras que abordam temáticas relacionadas com o Património Farmacêutico, a História da Saúde e com os actuais desafios da Humanidade na área da Saúde.

O Museu para difundir estes temas, tem publicado inúmeros catálogos de exposições e obras específicas, abordando a história da farmácia e a sua herança patrimonial. A última edição, em colaboração com o Clube do Coleccionador dos Correios, abordava o tema da cerâmica farmacêutica e a arte de curar.

O Museu tem igualmente participado em exposições temporárias em colaboração com outras entidades, das quais destacamos a exposição sobre Vasco da Gama e a Índia, na Capela da Sorbonne em Paris, em 1998, por ocasião dos 500 anos da descoberta do caminho marítimo para a Índia.

O Museu da Farmácia é um projecto que, ao longo dos anos, tem vindo a ser uma referência a nível nacional e internacional, como o comprovam os milhares de visitantes recebidos e os diversos prémios com que o Museu foi distinguido, dos quais destacamos:

- Prémio de Melhor Museu Português, 1997

- Prémio Almofariz, 1999

- Prémio Nacional de Designe de Comunicação, 2002

- Prémio APOM do Melhor Serviço de Extensão Cultural, 2008

Destacamos ainda a participação na fase final do Prémio de Melhor Museu da Europa de 2004, evento organizado pelo Fórum Europeu de Museus, em parceria com o Conselho da Europa, tendo o Museu da Farmácia sido distinguido com o "Nominated for the European Museum of the Year Award 2004". 
Em 2010, é a vez da cidade do Porto receber o Museu da Farmácia através da inauguração do espaço Professor Alberto Correia da Silva, que pretende homenagear este portuense pelo seu importante contributo na divulgação da história da farmácia e pela sua intervenção no exercício digno da profissão farmacêutica.

Em ambos os Museus, foram recriados espaços e ambientes, que permitem ao visitante aperceber-se, de uma forma mais imediata, a evolução da história e tecnologia da farmácia portuguesa desde o final do século XV até aos nossos dias. Reconstituições de autênticas farmácias portuguesas desde a antiga botica dos séculos XVIII e XIX até à Farmácia Liberal da Avenida da Liberdade em Lisboa do início do século xx. No Museu da Farmácia do Porto, o património da farmácia portuguesa está representado pela excelente reconstituição da Farmácia Estácio, situada na Rua Sá da Bandeira.

É de salientar ainda a reconstituição de uma autêntica farmácia tradicional chinesa, oriunda de Macau do final do século XIX e de uma área dedicada à Farmácia Militar.

A temática da Farmacia e da Saúde são abordadas com peças de extrema qualidade, oriundas de civilizações e culturas tão distantes no tempo e no espaço, como a Mesopotâmia, o Egipto, a Grécia, Roma, os Incas, os Astecas, o Islão, o Tibete, a China, o Japão e, finalmente, a Farmácia Europeia desde a Idade Média até 1929, com o isolamento da penicilina pelo cientista inglês Fleming. A exposição termina, com a exibição das farmácias portáteis usadas no Space Shuttle "Endeavour" na última viagem do milénio (Dezembro de 2000), para além de medicamentos da Estação Orbital Mir e da comida dos astronautas russos. 

UMA COLECÇÃO DE VASOS GREGOS 
(Página deixada propositadamente em branco) 
Depois de um período de egiptomania, que entusiasmou a Europa, sobretudo na primeira metade do séc. XIX, coube a vez à cerâmica pintada, encontrada principalmente em túmulos da Toscana e, como tal, supostamente etruscos, de ocupar a atenção dos coleccionadores. Só pelos meados do século é que A.R. Mengs e depois J.J. Winckelmann, o verdadeiro criador da História da Arte, lhes atribuiu a origem grega e a pertença àquele ramo do saber.

É certo que o coleccionismo principiara muito antes. Esboçado no Renascimento, generalizara-se sobretudo a partir da segunda metade do século XVIII, desde que Sir William Hamilton, representante britânico junto do Rei das Duas Sicílias, reuniu em Nápoles uma notável colecção, que veio a ser adquirida pelo Parlamento inglês, dando assim lugar, em 1772, à formação da primeira galeria de vasos gregos, a do British Museum. A esta seguiram-se muitas outras, entre as quais destacaremos a do Museu do Vaticano, a do Louvre, a do Metropolitano de Nova Iorque, a do Ermitage de S. Petersburgo.

Também em Portugal o gosto por este género de coleccionismo começou a florescer, pelo menos a partir dos primeiros anos do século XIX, graças a D. Manuel e a seu filho D. Alexandre de Sousa Holstein, quando nossos embaixadores em Roma.

A colecção, enriquecida pelos descendentes, deu entrada no nosso País pouco depois de 1834 (ou seja, da subida ao trono da Rainha D. ${ }^{a}$ Maria II), aumentada ainda pelos seus herdeiros, nomeadamente por D. Pedro de Sousa Holstein, que veio a ser o primeiro Duque de Palmela. Foi num palácio da família em Lisboa que me foi permitido estudá-la. Constava então de dezoito vasos, e o mesmo acontecia ainda quando de novo fui autorizada a vê-la em 1964. Se refiro estes pormenores, é porque começa aqui um exemplo do desmantelar da colecção: quando, em 2001, se realizou na casa-museu Dr. Anastácio Gonçalves a grande exposição Uma família de coleccionadores. Poder e cultura, desse notável conjunto apenas restavam dois vasos. O outro, a única ânfora panatenaica que se saiba existente no País, fora salvo a tempo, por eu estar prevenida de que ela ia a leilão e, em consequência, ter pedido ao meu Colega Professor Doutor Jorge 
de Alarcão, que tentasse conseguir junto do então Director do Museu Nacional de Arqueologia que exercesse do direito de preferência sobre essa peça, o que efectivamente aconteceu.

Pouco depois desta colecção surge entre nós outra, a do Rei D. Fernando II, aquele a quem José Teixeira chamou muito justamente, em livro publicado em 1986, o "Rei-Artista, Artista-Rei». Porém, as descrições das suas colecções conservadas não permitem uma identificação segura dos espécimes de cerâmica grega. Algumas pequenas peças vieram a ser recuperadas pela Fundação da Casa de Bragança e encontram-se expostas em Vila Viçosa. Mas as duas principais, dois vasos de grandes dimensões, oferecidos a D. Pedro V pelo Núncio Apostólico em Lisboa, por ocasião do seu casamento, tinham ficado no Palácio das Necessidades, pelo menos desde o falecimento de D. Fernando (1885), e nunca mais se soubera delas. Só quase um século depois é que o Professor Doutor Fernando da Fonseca os viu por ocasião de uma visita clínica ao Palácio de Belém e me conseguiu autorização presidencial para ir lá estudá-los. Uma vez identificados os pintores como artistas da Itália do Sul, um deles recebeu do maior especialista de vasos gregos dessa região, o Prof. Dale Trendall, da Nova Zelândia, a quem eu mandara fotografias, o nome de Pintor de Lisboa.

No Palácio de Monserrate, em Sintra, também Sir Francis Cook, o que teve a honra de hospedar Lord Byron, reuniu, segundo consta entre antiquários, uma colecção de uma dezena de vasos gregos, dos quais quatro, que pude estudar, se encontram em Lisboa, na posse de particulares.

Outras colecções maiores ou menores, mas sempre de valor, se foram formando ou desfazendo ao longo dos tempos. Algumas se constituíram também mais recentemente, entre elas ocupa lugar do maior relevo a do Dr. Manuel de Lancastre, que aceitou expô-la ao público em Lisboa, no Museu Nacional de Arqueologia, em 2007, e depois no Porto, no Museu Nacional Soares dos Reis, com o título "Aquém das Colunas de Hércules». Note-se que, além dos seus 28 vasos, todos de grande valor, um é assinado pelo Pintor de Brygos. 
Quer num caso quer noutro, a essa colecção juntaram-se outras. Assim, no Museu Nacional de Arqueologia, figuraram também as que anteriormente tinham sido doadas e objecto de exposição, a de D. Luís Brandão e a de Barros e Sá; no Museu Nacional Soares dos reis, a colecção Allen, o diplomata portuense de origem britânica, que fundara o museu portuense da Rua da Restauração, o qual depois passou a Museu Municipal e daí à sua actual localização.

Outro exemplo de exposição ao público de uma colecção particular é o que foi dado pelo Dr. António Miranda, que, em 2008, apresentou no Museu Municipal Abade Pedrosa, em Santo Tirso, a sua valiosa colecção de 18 vasos, em vários estilos.

Como pode deduzir-se desta sucinta enumeração, tem havido coleccionadores que reúnem preciosos espécimes, aos quais haveria que juntar ainda os adquiridos pelos próprios museus (de que são exemplo os comprados por Leite de Vasconcelos na Grécia ou encontrados em território nacional, nomeadamente em Alcácer do Sal - dos quais dois foram doados à Universidade de Coimbra). Mas também existem os que deixaram dispersar-se aqueles que compunham a sua própria colecção. Estão neste caso, além do já referido acervo da Casa Palmela, um pequeno mas valioso conjunto de quatro vasos que pertenceram à Marquesa da Póvoa de Santa Iria e que os seus herdeiros levaram a leilão em Londres.

A todos estes exemplos, aliás, não exaustivos - e não deve deixar de se referir o vaso do Museu Calouste Gulbenkian, o melhor de todos - há que juntar um caso especial. Trata-se da colecção de onze vasos de estilos variados pertencentes ao Museu de História Natural da Faculdade de Ciências da Universidade do Porto, por oferta dos museus de Berlim, juntamente com antiguidades egípcias e artefactos da Melanésia, em troca de um enorme conjunto de peças provenientes de escavações assírias feitas por um famoso arqueólogo alemão, Walter Andrae, pois o barco que as transportava tinha ficado aprisionado no Tejo. As diligências diplomáticas que conduziram a esta permuta, nos primeiros anos do segundo quartel do século xx, mostram como os severos métodos da arqueologia podem às vezes enredar-se nos meandros da política. 
Ao chegar a esta altura, perguntar-se-á certamente o leitor: mas, afinal, qual é o verdadeiro interesse dos vasos gregos? É, em primeiro lugar, o seu valor artístico. Embora hoje se penda para estudar de preferência outros aspectos - como os que são relativos às funções, mercado, comércio e suas rotas - são eles que nos permitem compreender a evolução da grande pintura grega, que, à parte alguns exemplos arcaicos, encontrados ultimamente, desapareceu por completo. Dela sabemos, por exemplo, que Polignoto foi capaz de sugerir a emoção e a representação do espaço. De Agatarco de Atenas, que delineou os princípios da perspectiva; de Apolodoro, que inventou o sombreado e o uso de cores mistas; de Parrásio, que atingiu a subtileza da linha; até que se atingiu o génio de Apeles. Estes dados, que nos são transmitidos por escritores gregos e romanos, que viveram entre o século de Augusto e o século II da nossa era, também se reflectem na pintura dos vasos, conquanto as suas cores estejam praticamente limitadas ao negro e ao vermelho do barro e ainda ao branco. Os vasos eram levados ao forno em três fases, em que a temperatura era sucessivamente elevada e baixada, segundo um processo que levou séculos a descobrir. É na X Ode Nemeia de Píndaro que encontramos um dos raros trechos em que se alude ao seu fabrico:

.... o recesso colorido dos vasos de barro, endurecidos ao fogo.

Assistimos, pois, a um longo percurso, entre o século x a.C. e o final do Iv a.C., em que termina. Principiando pelo desenho abstracto, passa depois ao protogeométrico e ao geométrico, como é costume chamar-lhes, que durante dois séculos (aproximadamente entre 900 e 700 a.C.) se desenvolve sobretudo em Atenas, embora se encontrem variantes em diversas regiões gregas, como a Argólida, a Lacónia, a Beócia e as Cíclades. Sofrendo a influência orientalizante nos seus motivos, designadamente a presença de animais, quer domésticos, quer selvagens, ou mesmo de monstros, e também elementos florais, é o coríntio que vai ocupar o primeiro plano entre 725 e 550 a.C. 
É aí que se origina a técnica das figuras negras, em silhueta sobre o fundo do barro. Mas é em Atenas que ela vai conhecer o seu esplendor, até que, cerca de 530-520 a.C., o esquema se inverte, dando lugar ao de figuras vermelhas sobre fundo negro. Quem o inventou, é uma das questões mais debatidas actualmente na história dos vasos gregos - até mesmo se foi ideia de um oleiro ou de um pintor, entre os quais Nicóstenes, Âmasis, ou Andócides. Tinha-se por certo, até há pouco, que aquele era o que, após o seu nome, assinava epoiesen (fez), e este egrapsen (pintou). Aos que não o fizeram - e são a maioria - atribuem-se nomes derivados da localização da sua obra principal (Pintor de Berlim), ou do tema (Pintor dos Nióbidas) ou de uma característica do seu estilo (Pintor da Linha Rubra) ou de outras particularidades ainda. Baseiam-se as identificações na aplicação do método de Morelli aos pintores do Renascimento, que se fundamentava na semelhança do desenho do rosto, das mãos e dos pés. É esse o processo empregado por Sir John Beazley e a sua escola.

Entretanto, no final do século $V$ a.C., começavam a aparecer os estilos da Itália do Sul (Lucânio, Apúlio, Pestense, Campaniense) e da Sicília, de que já apareceram uns vinte mil espécimes. Se estas escolas foram criadas por artistas que aprenderam em Atenas ou se por pintores áticos que ensinaram nessas colónias gregas, é ainda objecto de discussão.

Naturalmente que também as formas dos vasos apresentavam variações de tamanho e de feitio, relacionados como estavam com a finalidade a que se destinavam (para servir o vinho no banquete; para se ungir ou para ofertas funerárias; para perfumes e azeite; para fazer libações; para cosméticos e jóias; para cerimónias nupciais; para conservação e transporte de vinho, azeite ou água). Cada um tem a sua designação própria, muitas das quais figuram no glossário em apêndice.

Mas outro dos grandes valores da cerâmica grega é de carácter documental. As cenas que representam são, efectivamente, uma das nossas melhores fontes de informação sobre a vida diária. Proporcionam-nos também dados sobre as representações teatrais (sobretudo 
as da Sicília e da Itália do Sul), sobre a religião, a literatura (citando versos ou ilustrando poemas), a língua (quando as inscrições reproduzem a fala popular).

A colecção do Museu de Farmácia, em Lisboa, que aqui se apresenta, reúne catorze vasos, entre os quais seis em estilo coríntio, dois áticos, e três apúlios. Neste pequeno conjunto, há seis cujos pintores foram identificados, dos quais o Pintor do Vaticano 73 e o do Grupo da Aba são ambos coríntios; o Pintor de Safo é ático de figuras negras; o Pintor de Zannoni é ático de figuras vermelhas; o Pintor de Dario e o Pintor de Varrese são apúlios.

Todos foram criteriosamente estudados, incluindo os vasos plásticos em apêndice, e constituem assim um trabalho apurado de um conhecido arqueólogo, o Doutor Rui Morais, que é actualmente professor doutorado com agregação da Universidade do Minho, Presidente do Conselho Pedagógico, e Vice-Presidente do Instituto de Ciências Sociais, além de outros cargos.

Merece especial referência a sua carreira académica, dada a variedade da formação recebida. Efectivamente, cada um dos quatro anos cursados na licenciatura em História e Arqueologia decorreu numa Universidade diferente. Assim, frequentou o $1^{\circ}$ ano na Universidade do Minho, o $2 .^{\circ}$ na de Atenas, o $3 .^{\circ}$ na de Pisa, e o $4 .^{\circ}$ na de Coimbra. Especialmente importante é ter feito em Atenas duas cadeiras de opção sobre vasos gregos e ter sido discípulo do Professor Doutor Jorge de Alarcão, que mais tarde haveria de ser Orientador da sua Tese de Mestrado, em 1998, sobre As ânforas de Carvalheiras. Em 2005, novamente na Universidade do Minho, defende a de Doutoramento sobre Autarcia e Comércio em Bracara Augusta, a qual veio a ser também editada em inglês numa série oxoniense dos British Archaeological Reports. De outras publicações da especialidade foi coordenador tanto em Inglaterra (The Western Roman Atlantic Façade, 2010), como em Espanha (Ânforas romanas de Lugo, 2011). Às lucernas romanas tem igualmente dedicado a sua atenção. Presentemente já lhes consagrou dois livros, um às do Norte de África que se encontram no 
Museu D. Diogo de Sousa (2008) e outro, publicado nesta mesma série monográfica, pertencente ao Museu de Évora.

Grande parte da sua obra (que já conta quinze livros e cerca de uma centena de artigos, muitos dos quais publicados em Espanha) é consagrada ao estudo de Bracara Augusta. Além da já mencionada nesta área, refira-se ainda a colaboração no Catálogo do Museu D. Diogo de Sousa (2008), Cerâmicas de produção local de Bracara Augusta (2009, com Manuela Delgado) e, sobretudo, Bracara Augusta (edição da Câmara Municipal de Braga, 2010), de cujo prefácio extraio o primeiro parágrafo, que então escrevi:

Acompanhar o ritmo da vida de outrora numa cidade bimilenar, principiando pela sua fundação, com todo o ritual, na presença de um dos legados de Augusto, em 16 ou 15 a.C., depois pela sua refundação, uns dez anos depois, e tudo isto evocado numa prosa ao mesmo tempo fluente, elegante e natural e apoiada em dados literários, epigráficos e arqueológicos seguros é uma experiência sumamente gratificante, quer para especialistas, quer para simples curiosos do passado.

Como arqueólogo, a ele se deve também, entre outras descobertas, a da data do teatro romano e a localização do anfiteatro romano, e ainda a de um pequeno busto de bronze, que tudo indica que seja uma reprodução da Tyche bracarense, semelhante à de Antioquia, por Eutíquides.

De uma natureza diferente é o estudo que aqui se apresenta. Especializado também nesta área, como já vimos, o Doutor Rui Morais organizou um estudo com todos os requisitos de uma investigação desta ordem. Possam assim os leitores beneficiar do conhecimento de mais uma colecção de cerâmica helénica no nosso País. 

CORÍNTIOS 

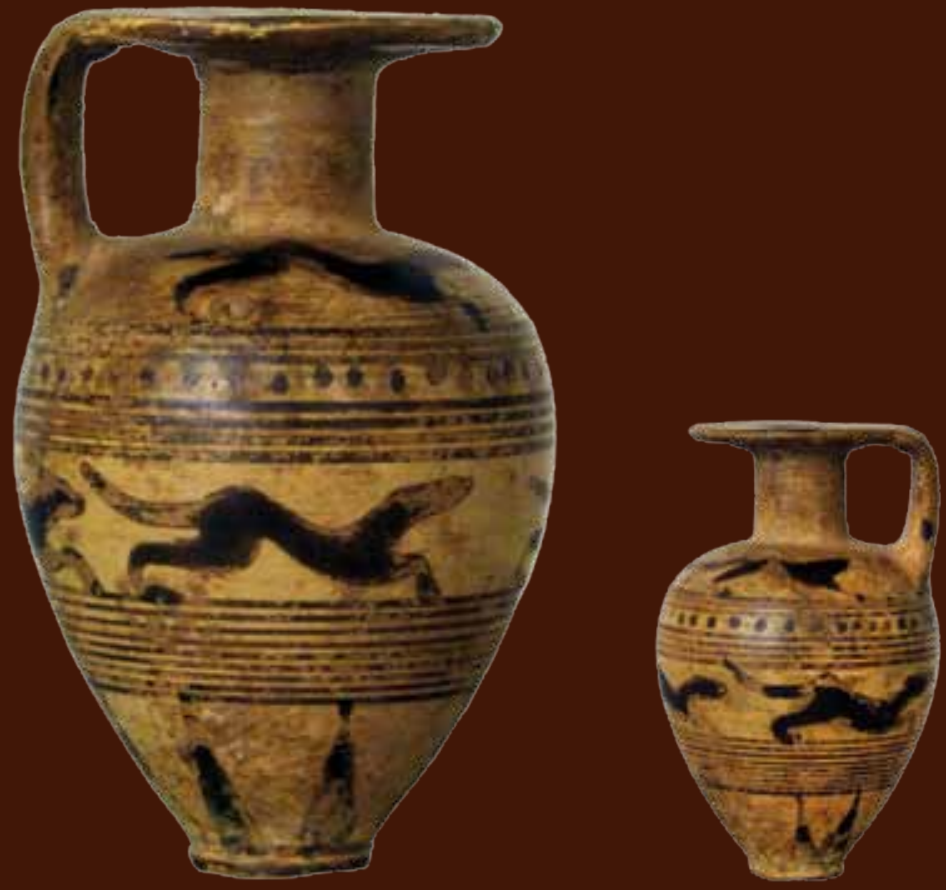

Alt:: $6,9 \mathrm{~cm}$;

Diâm.: $4,1 \mathrm{~cm}$ 
Arýballos ovóide

Proto-Coríntio

c. 650 a. C.

No Inv. 8022

Pintura negra/acastanhada parcialmente delida. No largo rebordo do gargalo, oito arestas raiadas espaçadas, limitadas no centro e no exterior por um friso. A asa, que arranca do rebordo e assenta na espalda, tem motivos delidos em ziguezague. Na espalda, dois cães de caça em silhueta correndo à direita, repetidos depois em número de três no bojo, entre grupos de finíssimas linhas paralelas preenchidas por frisos de pontos. Na base seis arestas raiadas, irregularmente espaçadas.

Pela forma bastante alongada e evoluída da transição do ovóide ao piriforme, a peça deve datar de c. de 650 a. C.

Cr. CVA Belgique (1). Bruxelles i (Musées Royaux d'Art et d'Histoire), III C Pl. 1.11,15; CVA Danemark (2). Copenhague ii, Pl. 82.6-8; CVA France (21). Paris xiii (Musée du Louvre) xiii, Pl. 40.2-3; CVA Deutschland (4). Braunschweig, (Herzog Anton Ulrich - Museum), Taf. 2.2; CVA Great Britain (16). Edinburgh (National Museums of Scotland), Pl. 4.3-4; CVA Italia (52). Gela I (Museo Archeologico Nazionale), Tav. 6.4-8, Tav. 7.1-5; CVA U.S.A. (1). Hoppin Collection, Pl. 1.7. 

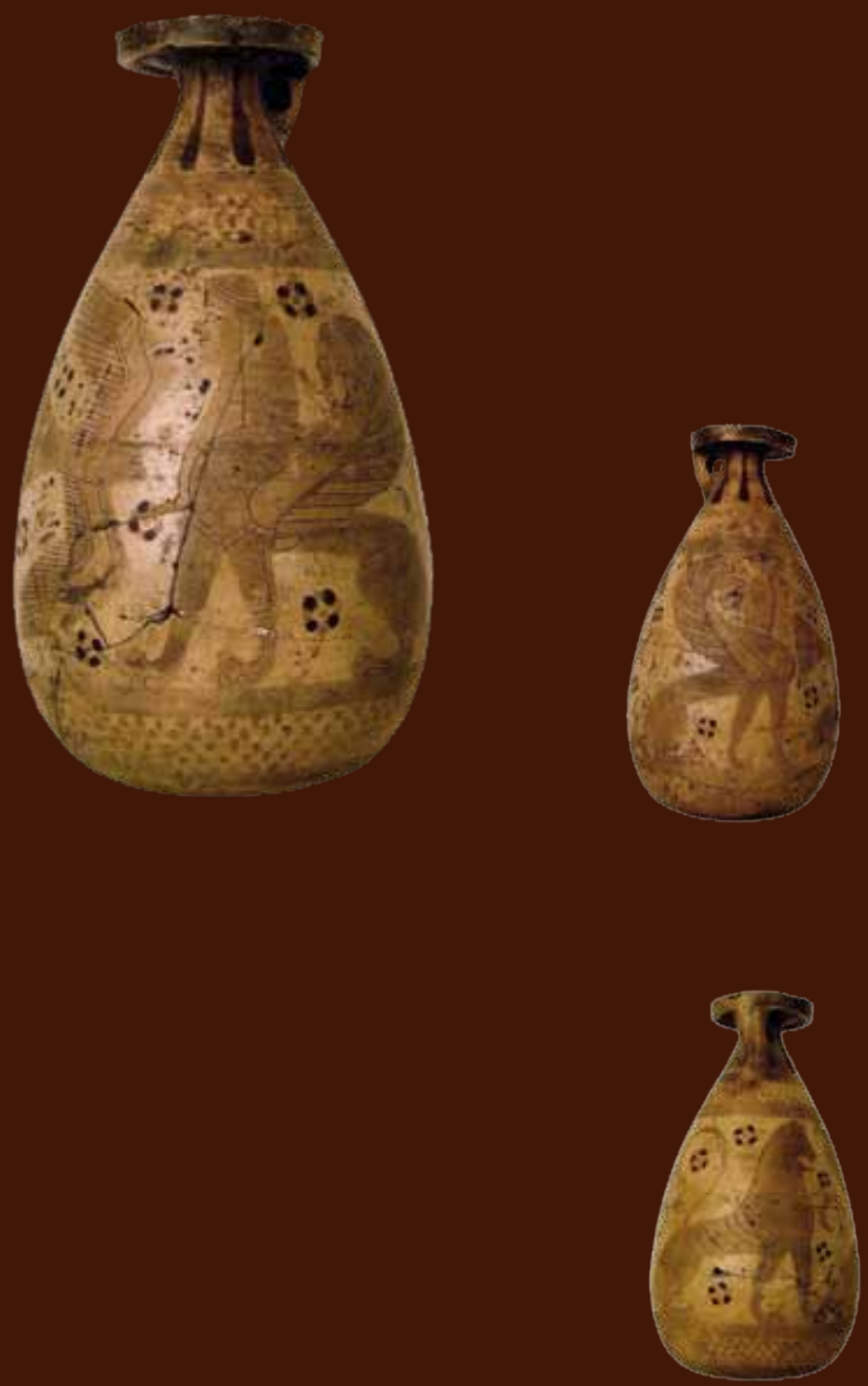

Alt.: 15,0 cm;

Diâm.:8,6 cm. 


\author{
Alábastron \\ Proto-Coríntio. \\ Pelo Pintor do Vaticano 73, c. 650-625 a. C. \\ $\mathrm{N}^{\circ}$ Inv. 8018
}

Decoração a castanho, com incisões, no fundo claro de cor bege clara; retoques a roxo em partes da decoração. Na base do gargalo e no colo, faixa de linguetas a vermelho. A asa, que arranca do rebordo e assenta no colo, é decorada com traços paralelos, verticais. A zona das figuras está delimitada, em cima e em baixo, por um friso, preenchido por linhas de pontos. Na parede, duas esfinges, heraldicamente afrontadas, separadas por um felino apoiado nas patas inferiores e com a cauda enrolada e uma ave em pleno voo. As esfinges estão apoiadas nas patas inferiores, com caudas enroladas e asas amplas e abertas. Da cabeça, ornamentada com uma fita, pendem longos cabelos representados com linhas onduladas; os olhos, grandes e alongados, estão desenhados inclinados para baixo. Retoques difusos de roxo no vulto, no colo e nas penas das asas. A preencher o espaço da decoração, rosetas de pontos a castanho e roxo.

Segundo William R. Biers, 1992, p. 49, as rosetas com pontos são características do final do período Proto-Coríntio. 


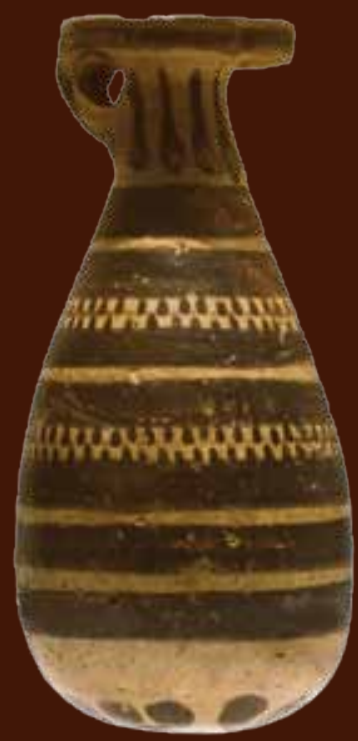

Alt.: 8,9 cm;

Diâm.: $4,3 \mathrm{~cm}$. 
Alábastron

Proto-Coríntio.

c. 620 a. C.

$\mathrm{N}^{\circ}$ Inv. 8020

Decoração a negro, no fundo claro da argila. No colo, uma faixa de linguetas. Na aba do gargalo e à volta do bojo a peça está decorada com frisos negros concêntricos delimitados por outros pequenos frisos concêntricos da cor da argila. No centro da decoração duas bandas de pontos. A asa, que arranca abaixo do rebordo e assenta no colo, é decorada com um traço paralelo, vertical.

Cf. CVA France (14). Paris ix (Musée du Louvre), Pl. 29.5; CVA Deutschland (36). Tübingen 1, Taf. 22.5; CVA Great Britain (9). Oxford (Ashmolean Museum), IIIC Pl. I.41; CVA U.S.A. (8). Fogg Museum, IIIC Pl. IV.13. 

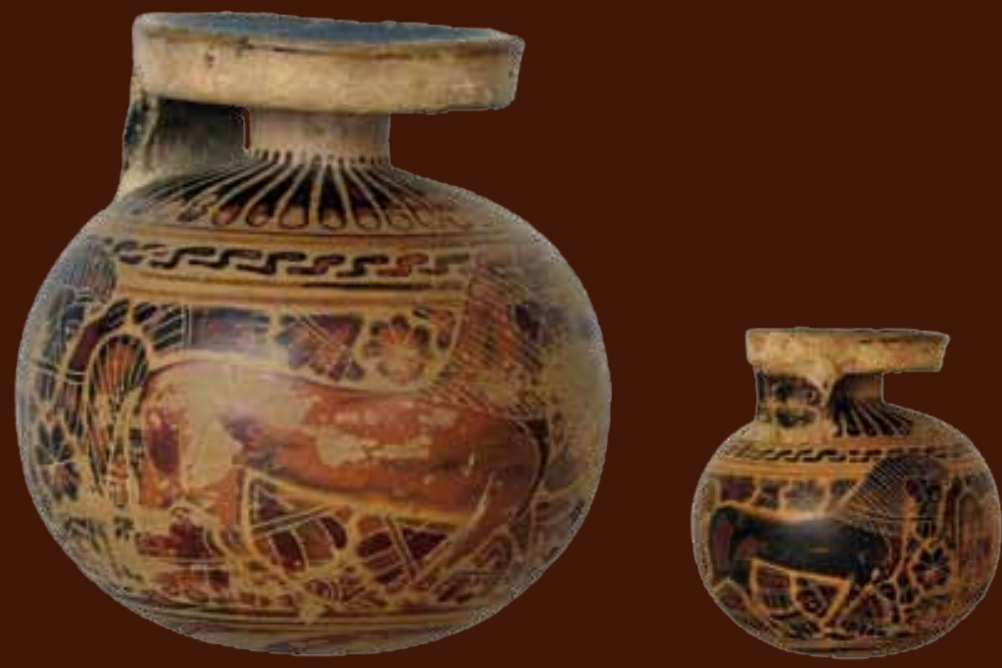

Alt.: $6,5 \mathrm{~cm}$;

Diâm.: 6,3 cm 


\section{Arýballos globular}

Transição Proto-Coríntio / Coríntio Médio.

c. 640-600 a. C.

No Inv. 8019

Decoração em negro lustroso, que nalguns sítios passa a castanho, com incisões. A aba do gargalo e a asa que arranca do rebordo e assenta na espalda estão preenchidas a negro. A espalda está decorada com arestas raiadas, sob um friso de linhas duplas concêntricas preenchido com uma linha de motivos em meandros. Corpo globular decorado com dois cavalos com arreios, à direita; numerosas rosácias e palmetas estilizadas a preenher o espaço. Retoques a vermelho nos cavalos e nos motivos florais. 

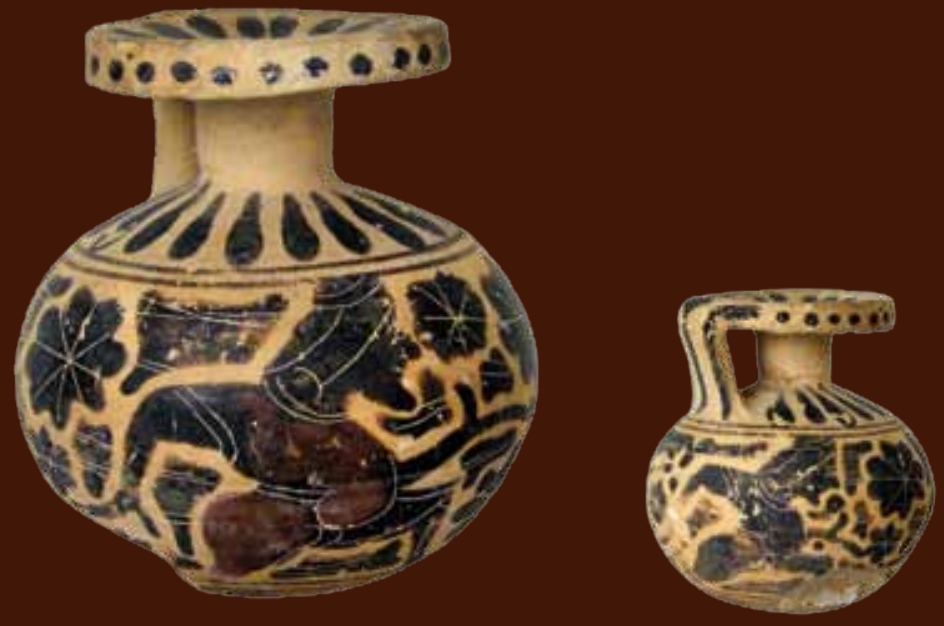

Alt: $5,9 \mathrm{~cm}$;

Diâm.: $5,5 \mathrm{~cm}$ 


\section{Arýballos globular Tipo Siana}

Coríntio Médio.

Atribuível ao Grupo da aba ("Flap-Group 1") de Axel Seeberg, c. 610 a. C. $\mathrm{N}^{\circ}$ Inv. 6938

Adquirido em leilão da Christie’s (Catálogo 1998, p. 135, no 286).

Decoração em negro lustroso, que nalguns sítios passa a castanho, com incisões. Na aba do gargalo, número apreciável de arestas raiadas e no rebordo linha de pontos. A asa, que arranca do rebordo e assenta na espalda, é decorada com traços paralelos, verticais. A espalda está decorada com arestas raiadas. Corpo globular decorado com dois gesticulantes komastai afrontados, de nariz afilado, sem barba, queixos proeminentes e mãos consideravelmente alongadas; a estilização do cabelo indica a sua desordem. Estes, visivelmente agitados, salteiam e dançam com os pés juntos; usam túnicas aderentes parcialmente pintadas a vermelho, com a gola evidenciada por incisões; as incisões estão também nas fitas que prendem o cabelo e no friso que atravessa o toráx dos komastai. Como é característico destas figuras, têm nádegas proeminentes em forma de "almofadas". Retoques a vermelho nas túnicas; numerosas rosáceas incisas e cachos de uvas muito estilizados a preencher o espaço.

Cf. Belgique (1). Bruxelles i (Musées Royaux d'Art et d'Histoire), III C Pl. 1.27,30a-b; CVA France (7). Paris i (Bibliothèque Nationale, Cabinet des Médailles), Pl. 13.8-9; CVA Deutschland (7). Karlsruhe i (Badisches Landesmuseum), Taf. 41.7-8; CVA Deutschland (16). Adolphseck ii (Schloss Fasanerie), Taf. 60.2; CVA Italia (52). Gela I (Museo Archeologico Nazionale), Tav. 25.1-5; CVA New Zealand (1), Pl. 36.7-13; CVA Schweiz (2). Zürich (Öffentliche Sammlungen), IID, IIIC Taf. 3.51-54; CVA U.S.A. (10). San Francisco Collections, Pl. II.4a-b; Seeberg, CKV. 

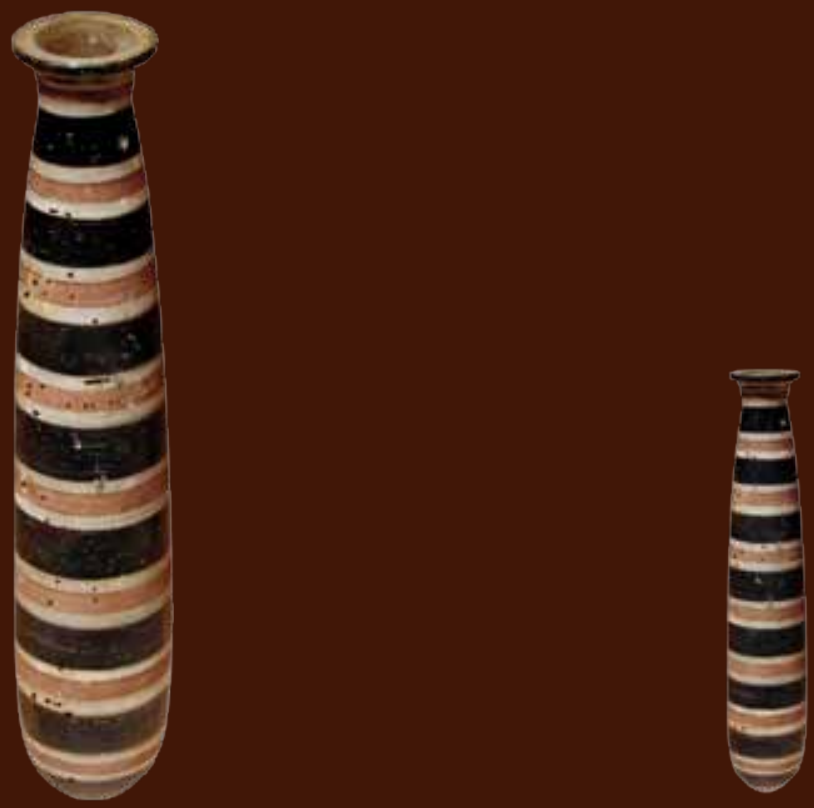

Alt.: $29,2 \mathrm{~cm}$;

Diâm.: $5,9 \mathrm{~cm}$. 


\section{Alábastron ("baton" form)}

Coríntio Tardio.

c. $600-575$ a. C.

$\mathrm{N}^{\circ}$ Inv. 9997

Alábastron em forma de "baton" que se vai adelgaçando desde a base arredondada ao gargalo, com aba esvasada. Decoração repetida com frisos de três círculos concêntricos que consistem num friso vermelho, mais largo, delimitado por dois estreitos frisos a bege. 

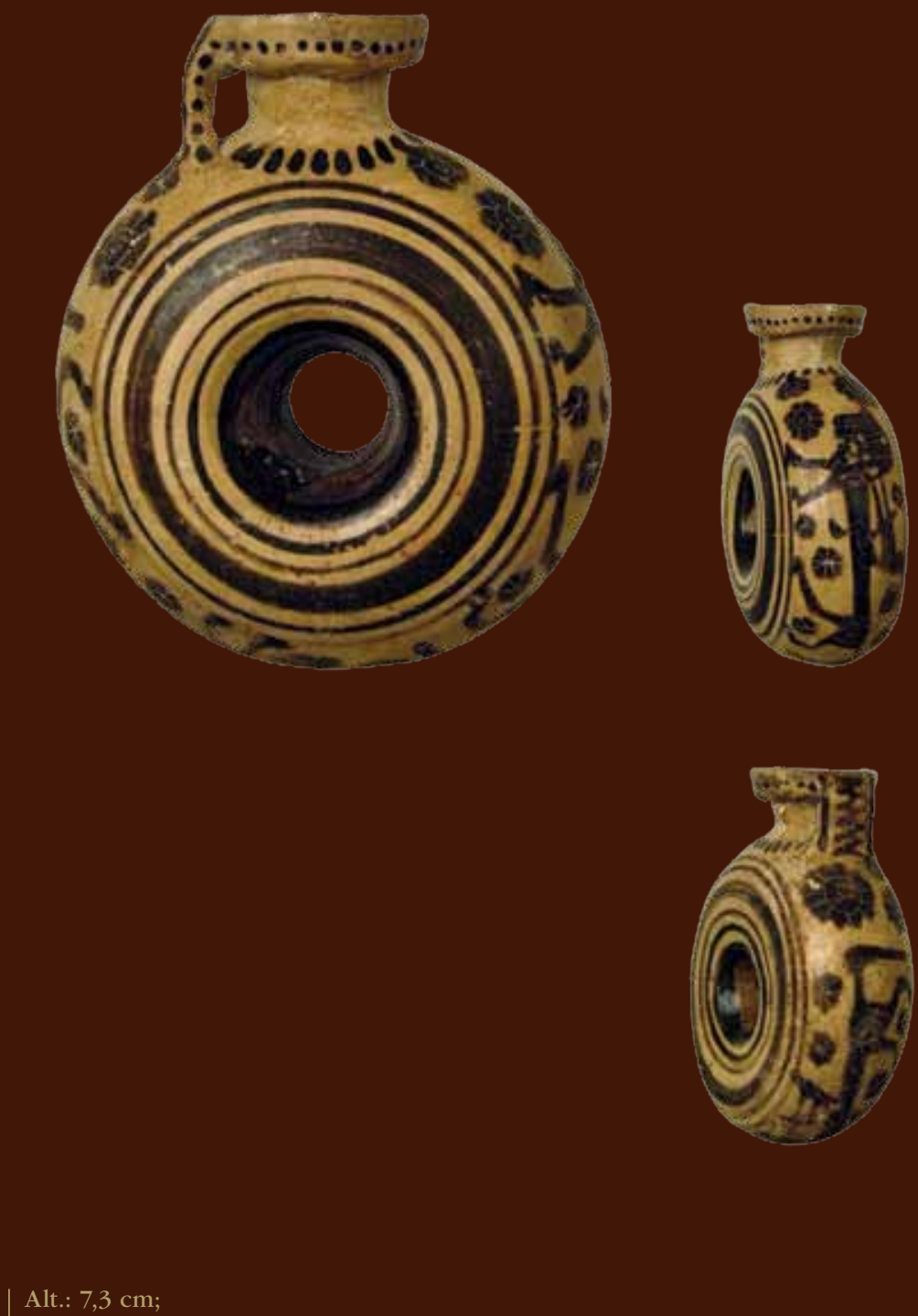

Diâm.:6,1 cm. 


\section{Arýballos anelar}

Coríntio Tardio.

c. 550 a. C.

No Inv. 10139

Decoração em negro lustroso, que nalguns sítios passa a castanho, com incisões. Na base do gargalo, pequenas linguetas raiadas; na aba um número apreciável de arestas raiadas e no rebordo linha de pontos. O interior do anel é negro. À volta do orifício central, de cada lado, frisos concêntricos. No exterior do anel, de cada lado, um sátiro com falo proeminente em cima de um leão de perfil muito alongado, ambos à esquerda; rosáceas de diferentes dimensões no campo, delimitadas por incisões. Asa plana, semi-circular, decorada com um motivo em zigue-zague separado por traços paralelos verticais, e motivos de pontos na face lateral.

Cf. CVA France (7). Paris i (Bibliothèque Nationale, Cabinet des Médailles), Pl. 14.3-4, 9-10; CVA France (12). Paris viii (Musée du Louvre), Pl. 21.1-6; CVA Deutschland (16). Adolphseck ii (Schloss Fasanerie), Taf. 60.8-10; CVA Deutschland (36). Tübingen 1, Taf. 36.6-11. 

ÁTICOS 

Alábastron

Ático de figuras negras.

Pelo Pintor de Safo, c. 500-490 a. C.

No Inv. 9477

Alábastron de parede alongada com pequenas aletas laterais que termina num pequeno gargalo de cor negra, com aba larga da cor da argila. Sob o gargalo, dois frisos decorados com folhas de hera sem elementos de ligação. A delimitar a decoração, em cima e em baixo, estreitos frisos concêntricos a negro. A parede é decorada com a representação de duas ménades à direita e de perfil; vestem um longo chitôn e himátion que pende do ombro esquerdo e usam sakkos para o cabelo. Uma das ménades volta a face na direcção da outra. Letras sem sentido fazem parte da ornamentação.

O nome do Pintor de Safo foi atribuído por C. H. E. Haspels, $A B F L$ 1936, p. 94, a partir da representação de Safo num Kalpis que se encontra em Goluchów no Museu Czartorysski (Polónia). Haspels caracteriza deste modo o seu estilo: as personagens do Pintor de Safo têm um caminhar leve e ágil com os joelhos ligeiramente dobrados e pequenas faces com narizes arrebitados como do Apolo Piombino; não convidam a uma contemplação séria.

John Boardman, ABFH 1988, p. 114, refere o Pintor de Safo como um dos artistas mais interessantes e criativos. Em ARFHI 1988, p. 114, Boardman refere que o uso do fundo branco foi muito utilizado 


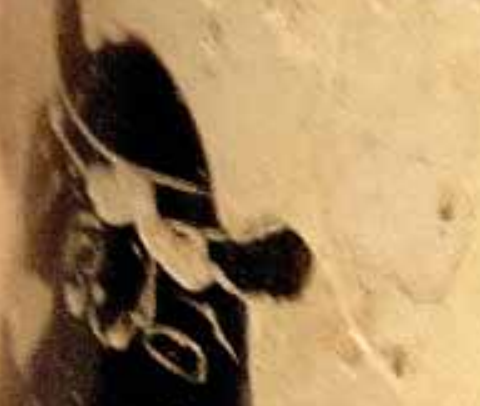

अ 0

4

1
4
4
4
$y$

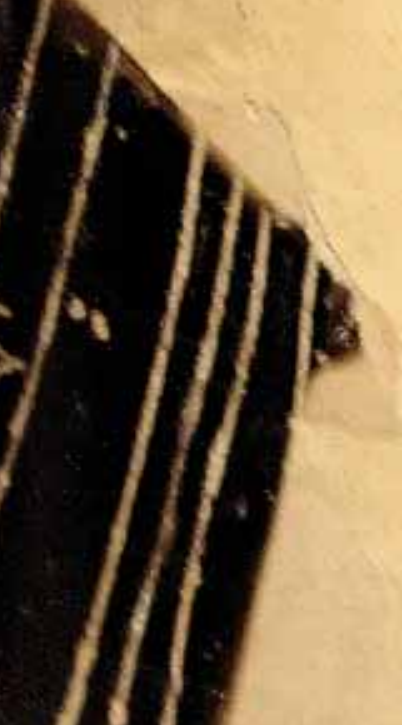

$\sqrt{2}$
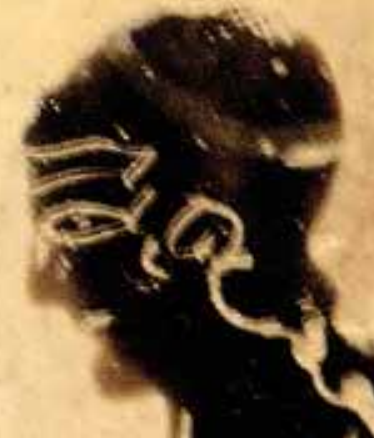
nas oficinas do Pintor de Safo e de Diophos com a representação de figuras a negro e com o uso da técnica das incisões. O mesmo autor, numa obra mais recente, The History of Greek Vases (2001: 63-64), refere que esta técnica, conhecida na bibliografia da especialidade como "Six tecnnique", era relativamente popular no período de transição dos finais do século VI a.C..

Trata-se de uma técnica iniciada por volta de 530 a. C., data que assinala um interessante período de transição na passagem da técnica de figuras negras para a de figuras vermelhas. Com base nos exemplos conhecidos esta técnica foi inicialmente usada para decorar lekythoi. Como vimos, de entre vários artistas (Haspels 1936: 106; Grossman, 1991: 17), consta o Pintor de Safo, conhecido por ter uma vasta produção nesta técnica, estando mais à vontade com ela do que qualquer outro pintor. As incisões demarcam os traços anatómicos, através da delineação de uma série de músculos. Os traços faciais são levemente incisos, em particular a linha do queixo e o olhar desvairado ("wild-looking eye"). O cabelo negro, brilhante, está demarcado por uma profunda e regular incisão criando um penteado com poupa.

Segundo Donna Carol Kurtz, $A W L$ 1975, 119, esta técnica nas mãos dos Pintores de Safo e de Diósforos corresponde a uma técnica transitória, em que partes significativas da composição são incisas sem acrescentar cor. A esta técnica chama "outline-Six", uma técnica transitória que emprega o uso de traços semi-delineados, característicos da transição da técnica de figuras negras (áreas pintadas incisas) para a técnica de figuras vermelhas (áreas delineadas).

Cf. CVA Espagne (1). Madrid i (Musée Archéologique National), Pl. 29.4a-c; CVA USA (24). Urbana-Champaign i (University of Illinois), Pl. 32.1-3; Haspells $A B L$, Pl. 32.2; Beazley $A B V$, p. 507-508, no 5; Beazley Addenda, pp. 60-61; ABL, pp. 94-130; 225-241; 368-369.

${ }^{1}$ O nome desta técnica foi atribuído por Jan Six em 1880, GazArch 13, pp. 193210; 281-294, e validada por J. D. Beazley, Greek Vases in Poland (Oxford 1928: p. 8). 

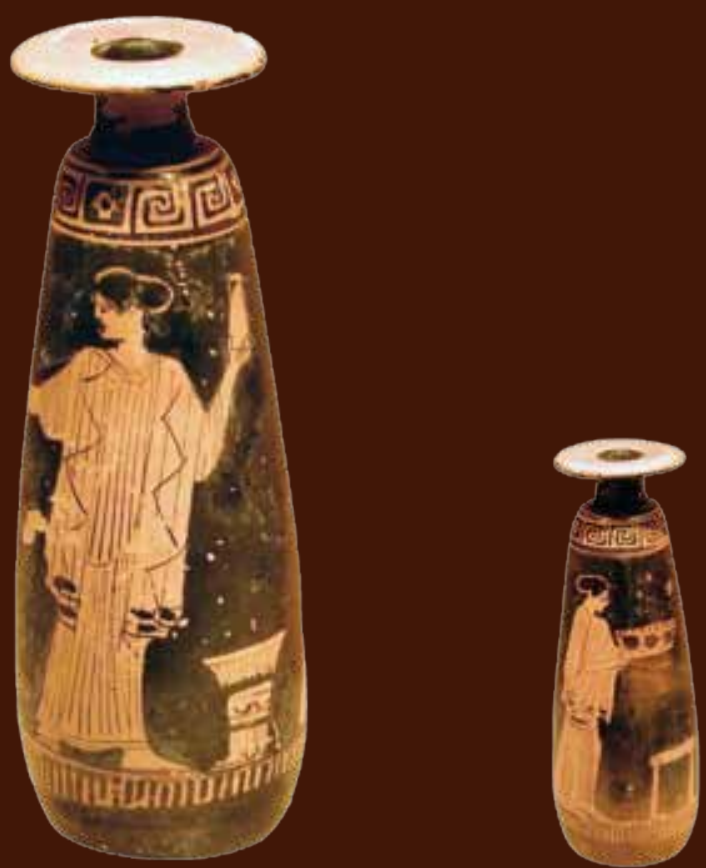

Alt.: $20,3 \mathrm{~cm}$;

Diâm.: $6,8 \mathrm{~cm}$ 


\begin{abstract}
Alábastron
Ático de figuras vermelhas.

Pintor de Zannoni, c. 450 a. C.

$\mathrm{N}^{\circ}$ Inv.8876
\end{abstract}

Alábastron com bojo alongado que termina num pequeno gargalo, com aba larga da cor da argila. Sob o gargalo, um friso decorado com motivos de meandros e de um trevo de quatro folhas (em forma de cruz). O bojo está decorado com duas figuras femininas, que vestem um longo chitôn e himátion e usam sakkos para o cabelo. Uma das figuras, representada de frente e a cabeça de perfil, à esquerda, segura na mão direita um alábastron (oferenda?); à sua frente, no canto inferior, está um altar decorado. A outra figura feminina, representada de perfil, à direita, segura nas mãos um kaneon; à sua frente, no canto inferior, um banco. A delimitar a decoração, em cima e em baixo, um friso de linhas segmentadas e paralelas, dispostas na vertical.

Cf. CVA Italy (54). Gela (Museo Nazionale iii), Taf. 40. 2-4; CVA Japan (1), Taf. 16, no 1; Beazley $A R V, 672-74$. 

APÚLIOS 


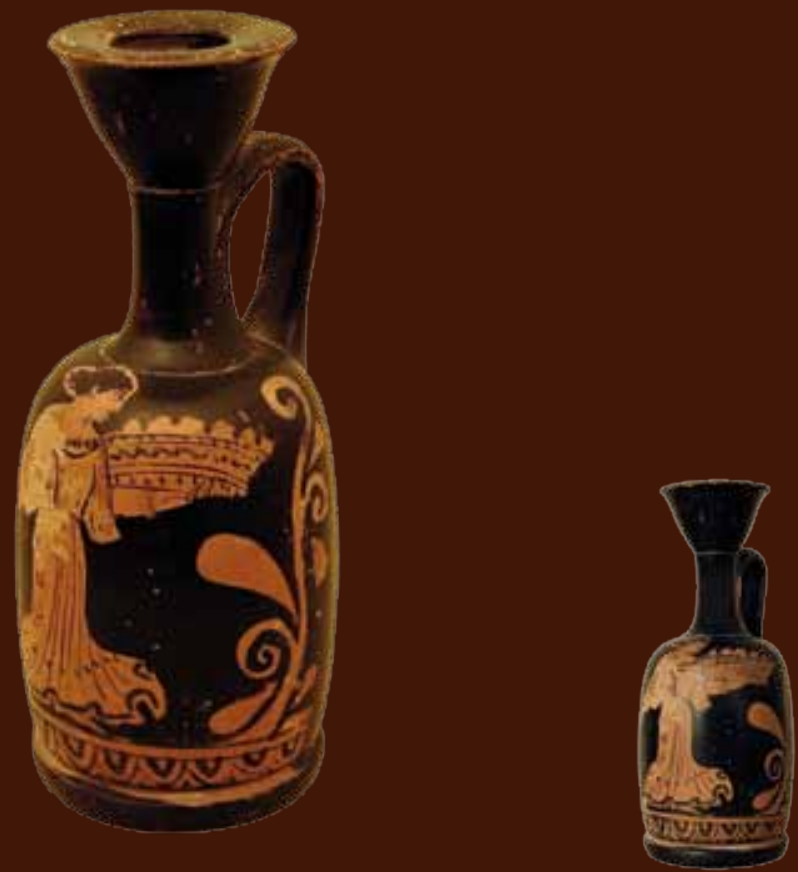

Alt.: $13,7 \mathrm{~cm}$;

Diâm.: 5,7 cm 
Lêkythos de figuras vermelhas

Apúlio.

Meados do séc. IV a. C.

$\mathrm{N}^{\circ}$ Inv. 8834

Na decoração reservada na parede do vaso está uma figura feminina posicionada a três quartos e a face de perfil, à direita; sustenta na mão direita uma cesta de grandes proporções, com oferendas; veste um longo chitôn cintado e está adornada com um colar de pérolas; os cabelos estão apanhados, possivelmente cobertos por um kékryphalos. Sob a asa e nos lados da figura, uma palmeta com festões laterais. Junto à base, um friso ornamentado com óvulos e pontos que delimita a decoração.

Uma forma de Lêkythos semelhante em CVA East Germany (Schwerin, Staatliches Museum i), Taf. 55, n 1-2. 


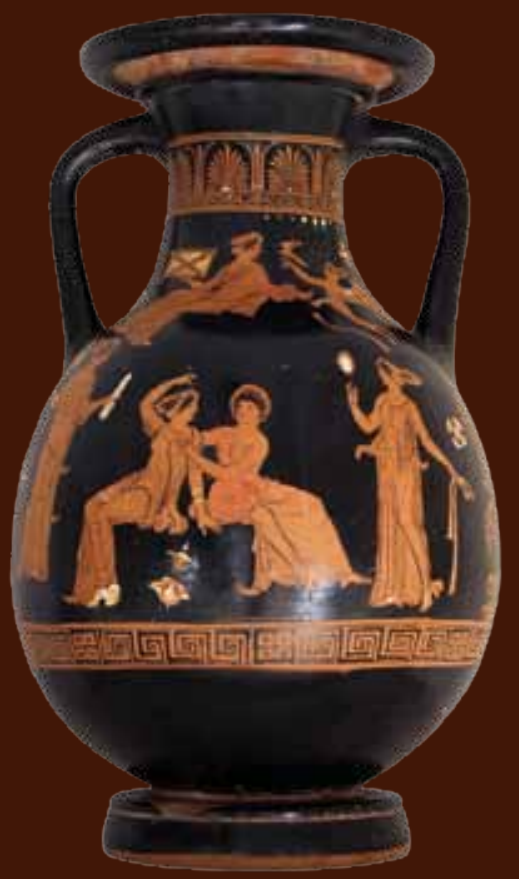

Alt.: $36,2 \mathrm{~cm}$;

Diâm.: 22,3 cm 
Pelike de figuras vermelhas

Apúlio, tardio.

Pelo Pintor de Dario, c. 340-330 a. C.

$\mathrm{N}^{\circ}$ Inv.8875

\section{A: cena nupcial.}

Em baixo, ao centro e sentado, um jovem semi-nu posicionado a três quartos, com clâmide à volta das pernas. Junto a este, uma mulher com torso a três quartos e pernas e cabeça de perfil, com a mão direita levantada acima da cabeça no acto de coroar o jovem; veste um ligeiro chitôn iónico de finas pregas, tem no colo um "xilofone" e está ornamentada com kekrýphalos, braceletes, brincos e colar. À direita e à esquerda duas figuras femininas, a três quartos e cabeça de perfil, olham para as figuras sentadas; ambas vestem um chitôn e usam o mesmo tipo de adornos da figura feminina sentada. A primeira segura na mão direita um espelho e na esquerda uma fita; a outra segura na mão direita um leque e na esquerda um alábastron. Na zona superior duas figuras: uma figura feminina a três quartos e de cabeça de perfil, com o mesmo tipo de vestes e de adorno das figuras femininas anteriores; com a mão direita segura uma caixa de presentes - um presente amoroso, nupcial, que supomos ser originalmente de madeira - símbolo da sua posição ou estatuto; à sua direita um Eros esvoaçante, de perfil, ricamente adornado, que tem na mão esquerda uma fita e na mão direita um pássaro que o acompanha em pleno voo (a ave deve ter um significado especial, talvez símbolo de união).

No colo, friso de palmetas, óvulos e linhas de pontos brancos.

\section{B: preparação da cena nupcial}

No centro uma figura feminina sentada numa rocha que segura na mão direita um espelho e na esquerda uma coroa. De cada lado, duas figu- 


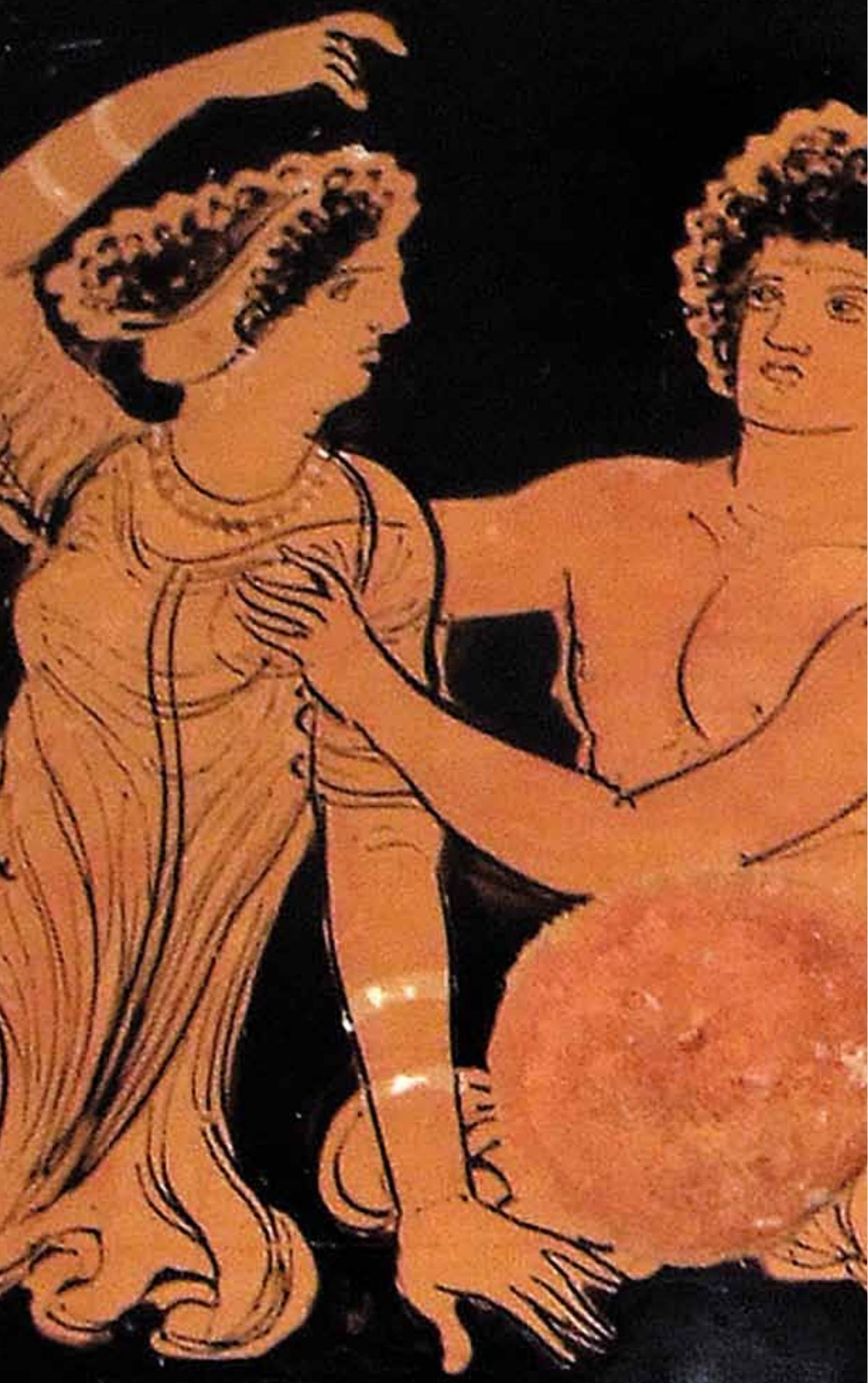


ras de pé, posicionadas a três quartos e de cabeça de perfil: à esquerda uma jovem que tem na mão direita uma caixa de presentes, idêntica à da figura feminina do anverso, e na mão esquerda uma coroa, praticamente delida; a figura masculina, à direita, corresponde a um jovem nu que segura na mão esquerda uma clâmide e na mão direita uma estrígil. As figuras femininas têm o mesmo tipo de adornos e de vestes das do anverso; o jovem usa uma fita branca no cabelo e argolas nos pés.

No colo, friso de loureiro mediado por uma roseta de nove pétalas.

Ambos os painéis estão decorados com motivos florais dispersos, representados por flores, rosetas de quatro pétalas e arbustos. Retoques de branco nos ornamentos florais e figurativos. Sob as asas, grandes palmetas duplas ricamente adornadas com festões.

Pensamos poder tratar-se de uma obra do próprio Pintor de Dario e não do seu círculo; vejam-se as fortes afinidades com as pelikai atribuídas a este pintor na obra de Trendall e Cambitoglou (RVAp, pp. 485; 491-492; Pl. 175, no 2, 3-4) e, em particular, o modo como representa as faces de perfil e o tratamento dos cabelos.

Trendall e Cambitoglou (RVAp, p. 483), referem o Pintor de Dario como um dos mais importantes do estilo Apúlio Tardio que muito iria influenciar os trabalhos dos seus contemporâneos e sucessores, dentre os quais o Pintor do Além. Segundo A. D. Trendall (RVSIS, p. 89) alguns vasos com a representação de cenas nupciais, especialmente em pelikai, foram muito populares nos seus associados e sucessores. Trendall caracteriza deste modo o seu estilo: "o Pintor de Dario é um pintor competente; ele gosta de faces a três quartos, com uma testa triangular à moda de Praxíteles, uma ligeira inclinação da cabeça e olhos e boca expressivos. As pregas da sua roupagem estão claramente definidas, mas tendem a desvanecer ao longo do corpo; o efeito ondulado das pregas que ele dá às vestes é bastante eficaz". 

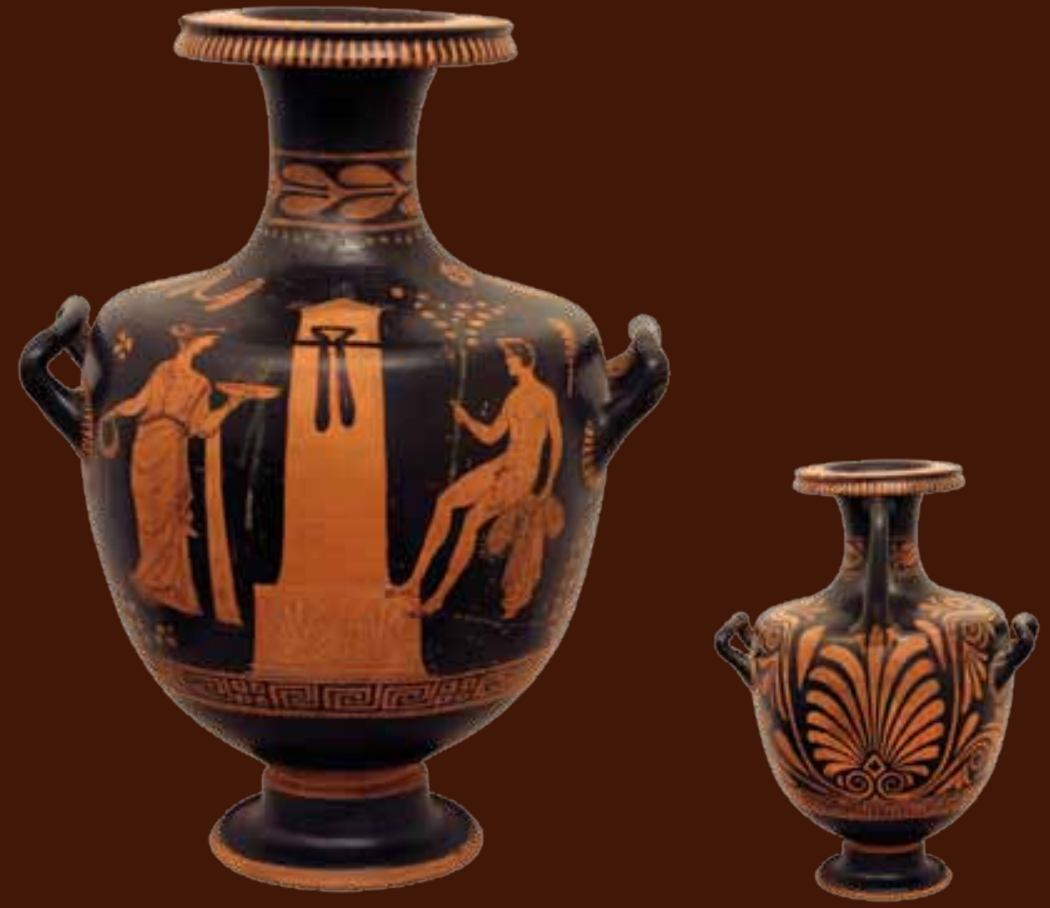

Alt.: 43, $4 \mathrm{~cm}$;

Diâm.: $25,6 \mathrm{~cm}$. 
Hýdria de figuras vermelhas

Apúlio.

c. 350-325 a. C.

Pelo Pintor de Varrese

$\mathrm{N}^{\circ}$ Inv. 8819

Cena fúnebre com a representação à direita de um jovem nu. Este está posicionado a três quartos e a cabeça de perfil; apoia-se na própria clâmide enrolada suspensa no braço esquerdo, decorada por uma fiada de pontos brancos. Na mão direita, levantada à altura do ombro, sustenta, como um ceptro, um longo ramo com folhas e frutos. Do lado esquerdo uma figura feminina, no acto de realizar uma libação. Está representada de frente e o rosto de perfil, com a perna esquerda para trás; segura na mão direita uma coroa, da qual pendem duas fitas esbranquiçadas, e na mão esquerda uma phiale, da qual igualmente pendem duas fitas brancas; veste um peplos cintado sem apotygma. Dois elementos arquitectónicos, que fazem lembrar fustes de colunas, ladeiam esta figura, sendo que o do lado esquerdo lhe parece servir de apoio. No meio, uma estela funerária da qual 


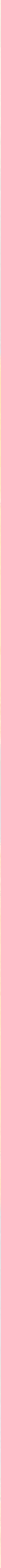


pende uma fita negra; as acroteras representadas no topo da estela e as palmetas representadas no plinto estão pintadas a branco.

No rebordo do bordo, linguetas a negro. No colo, ramo de loureiro reservado entre duas linhas concêntricas igualmente reservadas e uma fiada de pontos brancos. Na ligação das asas laterais, coroas de linguetas a negro. Sob a asa vertical, uma palmeta ladeada por festões laterais. Junto ao pé, larga zona reservada à volta do vaso, com decoração de meandros intercalados por cruzes. Na espalda da hýdria, duas fitas suspensas. Emprego abundante de retoques brancos nos motivos florais (ramos, arbustos e rosetas).

O Pintor de Varrese toma o nome do hipogeu Varrese em Canossa onde foram encontrados vasos de grandes proporções. Trata-se de um artista de alguma importância que exerceu uma considerável influência na Apúlia no terceiro quartel do século IV a. C. O seu estilo está relacionado com o do Pintor do nariz arrebitado ("Snub-Nose Painter"). Uma parte substancial dos seus trabalhos está reunida na Jahrb. Berl. Mus. 12, 1970, pp. 185-8, que apresenta vasos de grandes proporções com elaboradas cenas de teatro e de mitologia juntamente com peças menos pretensiosas, normalmente decoradas com duas figuras; é o caso de uma hýdria de Atenas (Trendall 1977, p. 173; Est. 96, c-d) e da hýdria aqui estudada. Em ambas se pode ver um dos atributos que identifica o desenho deste pintor: o uso de uma série de arcos paralelos, como se fossem linhas, que atravessam a túnica, entre os seios das mulheres.

Uma hýdria deste pintor em A. D. Trendall (1977), South Italian and Etruscan Red-Figured Vases in the National Museum at Athens. Atenas, p. 173; Pl. 96, no c-d. 

VASOS PLÁSTICOS 

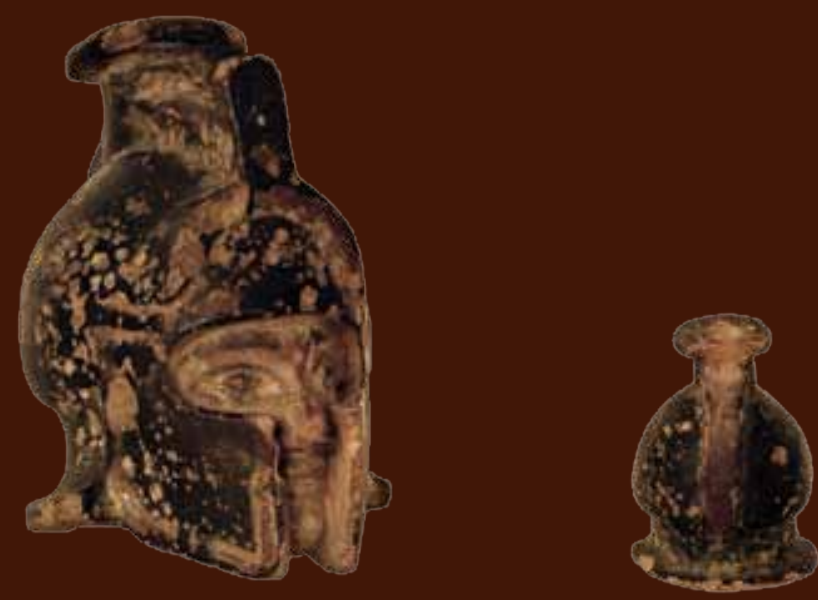

Alt.: $5,8 \mathrm{~cm}$;

Diâm.: 7,3 cm 
Arýballos moldado em forma de cabeça de guerreiro com elmo Ródio.

c. $600-590$ a. C.

$\mathrm{N}^{\circ}$ Inv. 8833

A cabeça do guerreiro está coberta por um elmo coríntio, cujo topo corresponde ao pequeno gargalo do vaso, com baixo colo cilíndrico e bordo plano, munido de uma asa larga. O elmo está recoberto por um negro lustroso que nalguns sítios passa a castanho, retoques a vermelho e branco. A crista do elmo corre da nuca até à fronte do guerreiro, delimitada por uma bordadura a vermelho; pontos vermelhos ao longo da crista. O rosto do guerreiro, imberbe, está reservado a claro, com o lábio inferior a vermelho; negro para o contorno dos olhos e as pupilas; branco para a córnea; negro para sobrancelhas e o bigode. As viseiras estão ornamentadas com duas rosáceas pontilhadas em branco. Uma rosácea análoga, mas formada por pontos brancos e negros, na parte frontal do elmo. De cada lado deste, uma flor de lótus com três pétalas. O fundo do vaso, sob o elmo, é largo e plano. 
Pelas características formais, proporção e ornamentações enquadra-se no Grupo E de Ducat, VPR (cf. CVA Deutschand (36). Tübingen 1, p. 29). O elmo utilizado pelo guerreiro neste vaso é uma variante iónica do chamado tipo coríntio.

Rodes especializa-se na primeira metade do século VI a. C. nestes pequenos e delicados contentores de perfumes, exportando-os em grande escala em todo o mundo Grego. Este tipo de vasos adquire uma grande variedade de formas, sendo que as cabeças com elmos e os bustos de mulheres foram das mais comuns, seguidos dos pássaros, animais, conchas e mesmo partes do corpo humano, tais como pernas ou, como no caso presente nesta colecção (n $\left.{ }^{\circ} 15\right)$, pés com sandálias (cf. Trendall 1979: 4).

Cf. CVA Belgique (3). Bruxelles iii (Musées Royaux d'Art et d'Histoire), III, II D e IB C Pl. 5.14a-b; CVA Danemark (2). Copenhague ii, Pl. 81.4; CVA France (15). Paris (Palais des Beaux - Arts, Collection Dutuit), Pl. 36.395; CVA Deutschland (9). München iii, Taf. 150.912; CVA Deutschland (10). Heidelberg 1, Taf. 4.6-7; CVA Deutschland (25). Frankfurt am Main 1, Taf. 11.3-4; CVA Deutschland (33). Berlin 4, Taf. 166.1-6; CVA Deutschland (36). Tübingen 1, Taf. 12.3-6; CVA Great Britain (9). Oxford (Ashmolean Museum), IID Pl. VII.3; IID Pl. VIII.1-4; CVA Italia (8). Firenze I, Tav. 3.8; CVA Pays-Bas (1). Musée Scheurleer i (La Haye), IID e IIIC Pl. 1.4, IB c-d Pl. 1.1; CVA Pologne (1). Goluchów (Musée Czartoryski), Pl. 7.2; CVA Schweiz (4). Basel 4, Taf. 19.5-6; CVA U.S.A. (8). Gallatin Collection, Pl. 33.5. 

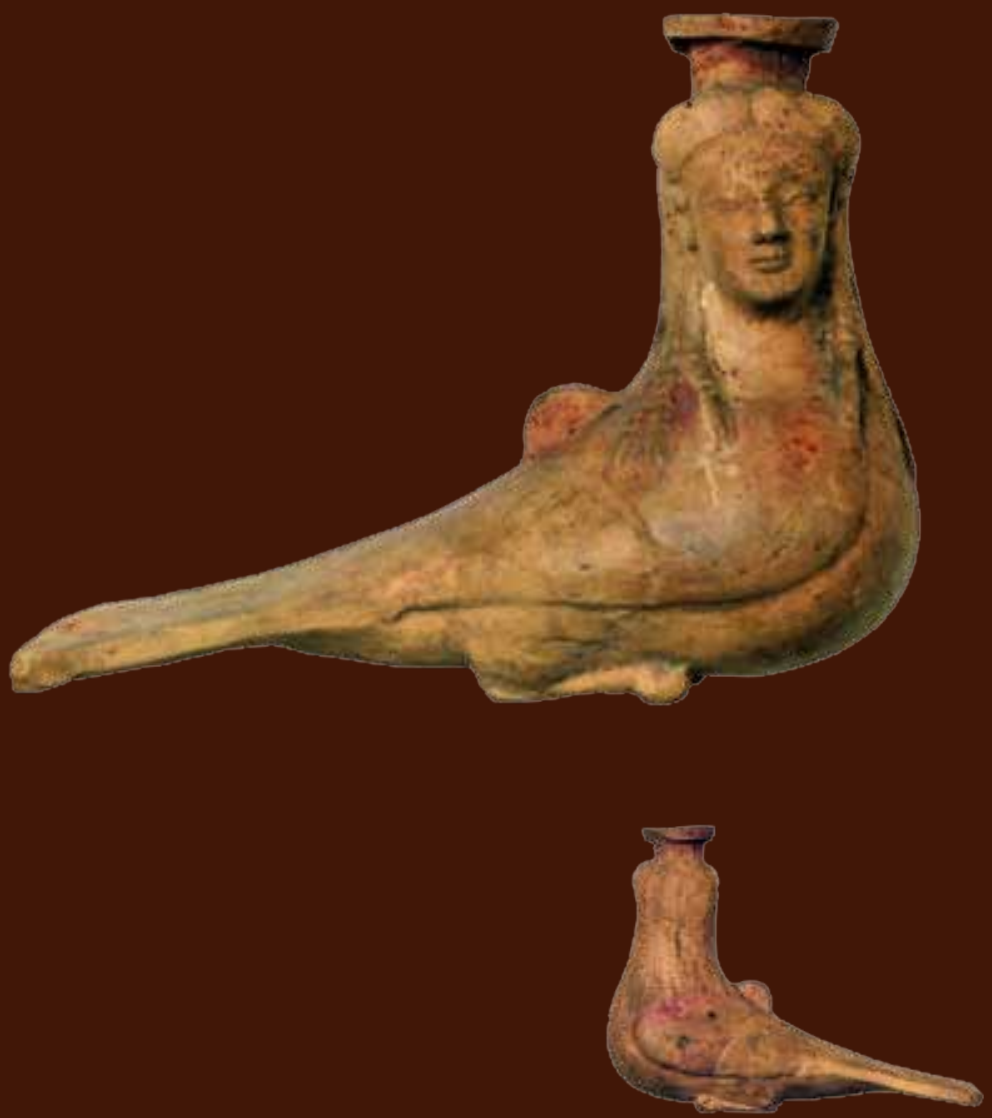

Alt.: $13,4 \mathrm{~cm}$;

Diâm.: 7,4 cm;

Comp: $17,7 \mathrm{~cm}$ 


\section{Arýballos moldado em forma de sereia}

Provavelmente de Samos, c. 550 a. C.

$\mathrm{N}^{\mathrm{O}}$ Inv. 6874

A cabeça é encimada por uma espécie de polos que serve de gargalo com rebordo. A sereia tem uma longa cabeleira entrançada, da qual pendem três mechas nos dois lados do rosto. A cabeça da figura está representada de frente e o corpo de perfil, à direita. As patas, dobradas, assentam numa pequena base. No dorso da sereia uma pequena asa não perfurada.

Estes vasos, feitos em moldes bivalves, são muito comuns no final do séc. VI a. C. (Biers 1986, 18).

Cf. CVA France (29). Rennes (Musée des Beaux - Arts et d'Archéologie), Pl. 5.1-2; CVA Great Britain (6). Cambridge i (Fitzwilliam Museum), II and III Pl. VI.6; CVA Deutschland (9). München iii, Taf. 151.4-7; CVA Pays-Bas (1). Musée Scheurleer i (La Haye), IID e IIIC Pl. 1.2; CVA Schweiz (4). Basel 4, Taf. 19.11; CVA U.S.A. (8). Gallatin Collection, P1. 33.12. 

Arýballos moldado em forma de pé direito com sandália

c. 550 a. C.

$\mathrm{N}^{\circ}$ Inv. 8021

Decoração em negro lustroso que nalguns sítios passa a castanho. Correias bordadas a negro, com incisões a delimitá-las. Na base do pé, a palmilha está preenchida a negro, com incisões. Gargalo negro, com rebordo, ligeiramente fracturado. Asa ausente por fractura.

Cf. CVA Belgique (3). Bruxelles iii (Musées Royaux d'Art et d'Histoire) III, II e IB C Pl. 5. 13a-b; CVA Schweiz (4). Basel 4, Taf. 19.15. 
(Página deixada propositadamente em branco) 


\section{GLOSSÁRIO}

Acroteras - extremidades ornamentais de um frontão de um templo ou de uma estela.

Alábastron - pequeno vaso, normalmente em alabastro, destinado a conter perfume. O termo estende-se, no entanto, a todos os vasos de forma cilíndrica, base arredondada, colo curto, sem asas.

Altar - base em pedra ou mármore usada para fazer libações às divindades.

Apotygma - tira formada pela parte superior do chitôn dórico ou do peplos.

Arýballos - nome convencional para um pequeno pote esférico ou globular com estreito colo cilíndrico e uma ou duas asas, usado para conter óleos ou perfumes.

Chitôn - longa túnica plissada usada pelas mulheres e, por vezes, pelos homens.

Clâmide - manto curto, preso pelo ombro, usado pelos cavaleiros, caçadores, viajantes e guerreiros com armas.

Eros - personificação do Amor.

Esfinge - monstro com a cabeça de uma jovem, corpo de leão e asas de pássaro.

Estela - laje vertical, usada frequentemente como monumento funerário.

Estrígil - raspador em bronze, próprio para retirar do corpo as gorduras e sujidade dos atletas.

Himátion - manto quadrangular feito de uma simples peça de pano.

Hýdria - vaso em cerâmica ou bronze munido de uma asa vertical e de duas outras laterais, dispostas na horizontal. Serviam primitivamente para ir buscar água ("hydor") à fonte. 
Kalpis - uma forma de hýdria criada no último quartel do século VI a. C..

Kekrýphalos - rede para o cabelo.

Komastai - foliões; dançarinos ébrios.

Lêkythos - pequeno jarro de uma asa, onde se guardavam os perfumes e óleos usados após o banho ou como oferenda aos mortos. Os lekythoi maiores destinavam-se ao uso funerário.

Ménades - seguidoras de Diónisos.

Óvulos - ornamentos em forma de ovo.

Pelike - espécie de pequena ânfora de parede arredondada.

Peplos - veste feminina de origem dórica, aberta de um dos lados, presa no ombro e aberta na cintura.

Phiale - taça para libação derivada de protótipos orientais, normalmente em metal. No mundo grego as phialai em cerâmica podiam ser usadas no simpósio.

Reservado - diz-se de uma parte, de um espaço desprovido de pintura.

Sakkos - touca para o cabelo.

Sátiro - seguidores de Diónisos, com caudas e orelhas caprinas.

Sereia - criatura híbrida com cabeça de mulher e corpo de pássaro ou com busto de mulher e parte posterior de pássaro. 


\section{ABREVIATURAS}

Beazley, $A B V$

BEAZLEY, J. (1955) - Attic Black-Figure Vase-Painters. Oxford.

Beazley, $A R V$

BEAZLEY, J. (1963) - Attic Red-Figure Vase-Painters. $2^{\text {nd }}$ ed. Oxford. 3 vols.

Boardman, $A B F H$

BOARDMAN, J. (1988) - Athenian Black Figure Vases. A Handboock. $2^{\text {nd }}$ ed. London

Boardman, ARFHI

BOARDMAN, J. (1988) - Athenian Red Figure Vases, the Archaic Period.

A Handboock. $2^{\text {nd }}$ ed. London.

Boardman, EGVP

BOARDMAN, J. (1998) - Early Greek Vase Painting. London.

CVA

Corpus Vasorum Antiquorum. Union Académique Internatioale.

Ducat, $V P R$

DUCAT, J. (1966) - Les Vases Plastique Rhodiens.

Haspels $A B L$

HASPELS, C. H. E. (1936) - Attic Black-Figured Lekythoi. Paris.

Kurtz $A W L$

KURTZ, D. C. (1975) - Athenian White Lekythoi. Oxford.

Seeberg, $C K V$

SEEBERG, A. (1971) - "Corinthian Komos Vases". University of London Institute of Classical Studies. Bolletin Supplement ( ${ }^{\circ}$ 27). London.

Trendall and Cambitoglou, RVAp.

TRENDALL, A. D.; CAMBiTOGLOU, A. (1982) - The Red-figured Vases of Apulia. Oxford. Vol. II - Late Apulian.

Trendall, RFVP

TRENDALl, A. D. (1963) - Paestan Pottery. A Study of Red-Figured Vases of Paestum. London.

Trendall, RVSIS

TRENDALL, A. D. (1989) - Red Figure Vases of South Italy and Sicily.

London. 
(Página deixada propositadamente em branco) 


\section{OUTRAS REFERÊNCIAS CITADAS}

BIERS, W. R. (1986) - "Some Plastics in Malibu", Occasional Papers on Antiquities, 2. Greek Vases in the J. Paul Getty Museum vol. 3. California, pp. 17-22.

BIERS, W. R. (1992) - Art, Artefacts and Chronology in Classical Archaeology. Routledge. London.

CHAMAY, J. and MAIER, J.-L. (1984) - Céramiques Corinthiennes. Geneva, pp. 66-67. SEEBERG, A. (1971) - "Corinthian Komos Vases", Bulletin Supplement 27, Institute of Classical Studies. London.

TRENDALL, A. D. (1977). South Italian and Etruscan Red-Figured Vases in the National Museum at Athens. Atenas, p. 173; Pl. 96, no c-d.

TRENDALL, A. D. (1979). Twenty years of Progress in Classical Archaeology. Sydney University Press for the Australian Academy of the Humanities. Sydney, p. 4; Pl. I, Fig. 2. 


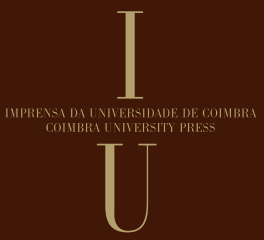

OBRA PUBLICADA COM A COORDENAÇÃO CIENTÍFICA

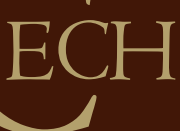

